\title{
“ERA UM NEGÓcio ARTESANAL E A GENTE TINHA GOSTO DE FAZER" Entrevista com Sergio Miceli
}

Esta entrevista parte do pressuposto de que há um diálogo a ser ampliado entre a sociologia dos intelectuais defendida e praticada por Sergio Miceli e disciplinas como a crítica e a teoria literárias. A abordagem, preocupada e comprometida com o tipo de centralidade do trabalho empírico por ele defendido, aposta num ambiente de debates no qual possa ser avaliado o alcance e o limite desse modus operandi no contexto desses diálogos latentes. A forma de responder, deixa ver que aposta semelhante orienta a generosidade intelectual de Miceli que, sem iludir-se com a própria franqueza, coloca-a à disposição da curiosidade do pesquisador.

Diferente de como se apresentam outras entrevistas que ele já respondeu, a arquitetura desta orienta-se a partir de uma gama de preocupações e recursos próprios à sociologia que auxiliam na construção de conteúdo sensível desde a fala de Miceli: a distinção entre sociabilidade e socialização. A sociabilidade sendo entendida para fins da entrevista como perguntas que dessem conta das preocupações com a manutenção de capital social das relações entre os intelectuais e a socialização como processo de incorporação dos saberes específicos ligados ao métier. De maneira que as perguntas abrem portas para uma reflexão que normalmente é feita de forma a sobrepor dinâmicas que obedecem a lógicas distintas de apreciação de si nas narrativas intelectuais.

A entrevista aconteceu em São Paulo, noapartamento de Sergio Miceli, em 13 de maio de 2015. Durou 1:33h. Todas as questões estão contempladas aqui, entretanto a divisão em três partes e seus tópicos, assim como a 


\section{2 - Remate de Males 36.2}

sequência das perguntas, foi editada a posteriori em função de uma rápida reflexão sobre possíveis rendimentos analíticos da conversa. Apesar da linguagem fática, as interrupções, pausas, etc. serem importantes para a análise sociológica e terem sido cuidadosamente transcritas por Hélio Roberto De Francischi Chagas, prevaleceu para fins desta publicação o critério da limpeza da linguagem, orientado para a fruição do leitor, numa edição que procurou manter o ritmo da oralidade sem com isso perder o teor dos conteúdos da fala.

João Paulo Lima e Silva Filho São Paulo, dezembro de 2015 


\section{PARTE 1 - SOCIALIZAÇÃO ACADÊMICA: TENSÕES ENTRE FORMAÇÃO, APRENDIZADO E PRÁTICA SOCIOLÓGICA}

\section{FORMAÇÃO E APRENDIZADO: A COMPOSIÇÃO ENTRE PUC- RJ, USP E ÉCOLE PRATIQUE DE HAUTES ÉTUDES - PARIS.}

\section{1 - JPF: Onde, como e com quem você aprendeu a fazer sociologia?}

Acho que a experiência na França foi decisiva. Havia feito uma graduação bastante interessante na PUC do Rio, no seguinte sentido: eu e meus colegas - e não é por acaso que a turma deu uma leva grande de sociólogos profissionais da minha geração - tivemos um curso bom, porque tínhamos professores que estavam começando a ousar em domínios que não eram ainda explorados na época: sociologia do conhecimento, sociologia da literatura, por exemplo. Tive professores como Costa Lima no início da carreira. Íamos na casa dele, onde fazíamos seminários. Ele estava começando a ler as coisas meio junto com a gente. Li um monte de autores: Auerbach, que quando eu cheguei em São Paulo ninguém conhecia. Tive uma iniciação com Cesar Guimarães em sociologia do conhecimento. Não li apenas Mannheim, mas outras obras de sociologia do conhecimento instigantes. Tivemos outros professores que tinham mais ou menos a nossa idade, como a Aspásia Camargo. Estavam começando. Não eram veteranos ensinando especialidades que estavam compartimentadas. Era uma turma arrojada, o que era provocativo. Desigual, mas interessante. Talvez com uma formação melhor nessas disciplinas esquisitas e pior na formação básica como nós teríamos na USP, por exemplo.

No mestrado aqui na USP, o que foi novo para mim, quem eu achava mais interessante não era o pessoal das ciências sociais. Fui fazer cursos na filosofia e nas letras. Fui aluno do Rui Fausto, do José Arthur Giannotti, do Bento Prado Jr., do Antonio Candido. Comecei a ter uma formação de que era carente na graduação. Lá tive Marx sumário, mas tive Marx de fato aqui. Mas isso ainda não é aprender a fazer sociologia, é formação. $\mathrm{O}$ mestrado ${ }^{1}$ foi negociado de maneira complicada, porque houve de início a recusa do objeto: não queriam nada que tivesse a ver com indústria

1 Mestrado em Ciências Sociais. Universidade de São Paulo, USP, Brasil. Título: A Noite da Madrinha. Ensaio sobre a Indústria Cultural no Brasil. Ano de Obtenção: 1971. Orientador: Leôncio Martins Rodrigues. 
cultural, o assunto não estava na lousa dos projetos do Florestan. Na verdade, o meu mestrado só se viabilizou quando eles foram aposentados, porque daí a minha turma foi pressionada pelos professores a terminar as teses rápido. Como eu tinha já o trabalho ensaiado sobre os programas de auditório, eles permitiram. Mas digamos que foi feito meio isolado... ninguém me ajudou muito. Foi da minha cabeça o trabalho. Com todas as limitações que eu tinha na época.

Onde eu aprendi a fazer sociologia foi na França. Vendo as pessoas fazerem pesquisa. Fiquei dois anos e tinha a mesa numa das salas do grupo do Pierre Bourdieu. No miolo do então Centro de Sociologia Européia. Éramos poucos orientandos, então nós convivíamos de perto com os assistentes: com Claude Grignon, Jean-Claude Chamboredon, Luc Boltanski. Nós íamos almoçar juntos, saímos em grupo no fim de semana. Foi esse convívio e o treinamento de pesquisa. Não estava apenas fazendo minha pesquisa, estava fazendo e vendo as pesquisas a cargo dos demais pesquisadores, pesquisa quantitativa, levantamento estatístico, prosopografia. E tinha ainda outra prática valiosa, o fato de que o andamento, o progresso de nosso trabalho, era avaliado através de textos que ele [Bourdieu] lia, discutia e palpitava, num momento em que dispunha de mais tempo para os orientandos em começo de carreira. Ele vinha ao Centro quase todos os dias, ficava lá, auxiliado pelos assistentes que também liam o trabalho dos orientandos e assim eu aprendi um bocado. Por exemplo: "Poder, sexo e letras na República Velha, estudo clínico dos anatolianos", o artigo que saiu na Actes $^{2}$ antes de eu voltar para o Brasil, representa bem a síntese dessa experiência. É algo que eu não saberia fazer sem esse aprendizado.

\section{2 - JPF: A revista Actes de la Recherche teve um significado específico na sua formação?}

Teve, porque eu a vi nascer e participei desde o início. Logo entrei nessa embrulhada em que ele [Bourdieu] me pôs: o desafio de escrever um texto para a revista antes de eu voltar para o Brasil. Coisa que todos os assistentes disseram: "É uma loucura você obrigá-lo a fazer um negócio desses. Temos seis meses para isso." Mas ele fez questão. Insistiu dizendo

2 Abreviação usada por Miceli para se referir à revista Actes de la Recherche en Sciences Sociales. A pergunta 2 trata especificamente sobre esta revista. 
que para mim seria importante. Ele tinha razão, era mesmo. Com essa história de ter que escrever para a revista no início, vendo a revista se forjar - porque era tudo feito nas salas e nas mesas ao lado da minha - eu via as provas, o projeto da capa, a proposta das matérias sobre arte, de como é que seria a maquete, eu assisti a tudo isso. Eu não tinha a ideia de que nós estávamos fabricando uma coisa teórica, longe disso. Era um negócio muito artesanal e a gente tinha gosto de fazer. Uma iniciativa de equipe, coletiva. Claro, havia certa concorrência entre os assistentes, que sempre estavam se bicando. Estavam disputando o amor do patrão. Mas a dinâmica entre os orientandos era diferente. $\mathrm{O}$ que a revista virou depois que eu já tinha voltado... com dez anos, a revista se converteu no veículo farol de certa orientação teórica. Uma espécie de vademecum sociológico, mas eu não vivi isso, eu participei dos anos inaugurais. Depois, quando voltei a escrever para a revista, recentemente, foi o artigo do Borges, ${ }^{3}$ já era outra situação, ele [Bourdieu] tinha morrido.

\section{3 - JPF: Como é que você chegou a Bourdieu? Foi um convite? Escolha?}

Eu cheguei e ele chegou a mim... foi uma relação negociada, por assim dizer... eu tinha começado a ler e me interessei - eu até já expliquei isso em outra entrevista. Eu ajudava muito na Editora Perspectiva a propor títulos na área de ciência sociais, então, como gostava das coisas dele, propus uma antologia e o Jacó Guinsburg, o editor, topou. Eu escrevi ao Bourdieu. Já tinha comprado A Reprodução e outros livros dele na livraria francesa. Já estava em São Paulo. Ele me respondeu propondo uma série de textos para eu ler, trabalhos que eu não conhecia, por exemplo, o posfácio que acabara de redigir para a edição francesa de Arquitetura Gótica e Pensamento Escolástico, do [Erwin] Panofsky. Ele me enviou alguns artigos dizendo: "Bom, vê aí o que você acha que, em termos do Brasil, faz mais sentido." Então, dessa remessa fiquei fascinado pelos textos sobre o campo religioso, que eu não conhecia, só havia lido um deles, o menor. Não conhecia o texto ambicioso. Após a leitura dessa leva, entendi que seria difícil extrair trechos de livros e acabei propondo o

3 Trata-se do artigo de Miceli "Jorge Luis Borges, histoire sociale d'un " écrivain-né »" publicado no ${ }^{\circ} 168$ da revista Actes de la recherche en sciences sociales, 2007. 
sumário com uma seleção de artigos. Foi tudo negociado durante meses, por meio de cartas, dava um passo e logo ele reagia. Escrevi a introdução ${ }^{4}$ e o livro [A Economia das trocas simbólicas] saiu. Ele decerto gostou do resultado e da introdução. Salvo engano, foi a primeira ou a segunda coletânea de Bourdieu em língua estrangeira, nesse sentido era iniciativa pioneira. Sei que ele ficou muito impressionado com a introdução porque anos depois, quando eu estava dirigindo a Edusp e fiz o Economia das Trocas Linguísticas, que é o $O$ que Falar Quer Dizer ${ }^{5}$ para o qual redigi uma introdução curta, ele me mandou um e-mail de gozação: "Agora está famosão hein? Acha que já dá conta do meu livro com três páginas..." [risos]. "A força do Sentido" tinha sei lá... cinquenta páginas. Eu era um jovem que queria se lançar. Outro momento. Logo após a publicação do livro, surgiu a chance na Fundação Getúlio Vargas de realizar o doutorado no exterior. O consulado francês dava a bolsa, a embaixada francesa parecia empenhada. Escrevi lhe perguntando se me aceitaria como orientando, e fui aceito de imediato, sem pré-condições. Se não me falha a memória, o livro foi o grande trunfo: "Você fez o livro, eu aceito." Eu organizei o livro antes de iniciar o doutorado em Paris, não depois.

\section{4 - JPF: Nessa época em que você foi a envergadura do Bourdieu ainda não era gigantesca?}

De jeito nenhum, ele estava começando a carreira. Quando fui ele tinha voltado da primeira viagem aos Estados Unidos, se não em engano.

\section{- JPF: Ele já tinha publicado A Distinção?}

Não, salvo engano. A Distinção foi feita nos anos 70 [publicada em 1979]. Eu preciso ver na bibliografia... mas eu acho que $A$ Distinção não, o que tinha saído era Un art moyen, sobre fotografia, a monografia sobre o público dos museus, A Reprodução, os dois livros sobre os estudantes de 68, e sobretudo Le métier du sociologue; foram livros muito importantes para mim. Quer dizer, para mim e para toda minha geração de cientistas sociais

\footnotetext{
4 O título da introdução é "A Força do Sentido". Miceli a retoma mais adiante na mesma resposta.

5 Trata-se do livro A Economia das trocas linguísticas: o que falar quer dizer de Bourdieu, traduzido por Miceli entre outros.
} 
no Brasil. Nós líamos Le métier du sociologue como se fosse um missal, um livro de orações... Você abre o missal e vai se deixando impregnar... O meu volume é bem desgastado, todo anotado... Eu li tanto, lia, relia... A gente usava aquilo como um manual de instruções indispensáveis. Foi o grande livro pedagógico da minha geração, no estilo vademecum.

\section{5 - JPF: Como você concebe o discernimento entre as formas de pensar a relação da ação social e da vida cultural? Estou pensando aqui na sociologia da cultura, na história das ideias.}

A formação na França, acho que modelou muito essa pergunta, quer dizer, o jeito de lidar com o desafio. Qual foi o meu aprendizado, não apenas conceitual, mas o aprendizado das tradições em sociologia da cultura? Lá eu comecei a ler de forma sistemática os grandes autores da sociologia da cultura contemporânea - [Raymond] Williams, [Fritz] Ringer, [Richard] Hoggart. Também a tradição da história social da arte... Bourdieu era absolutamente obcecado. Ele obrigava a gente a ler [Frederick] Antal, Panofsky, [Edgar] Wind, Klingender, Hauser e outros. Nós tínhamos que absorver a história social da arte, isso era básico. Ele dizia: "Como é que vocês vão trabalhar com atividade cultural sem conhecer história social da arte?" Não dava a menor pelota para sociologia das ideias, história das ideias... História das ideias era algo quase descartado no grupo. Bourdieu tinha horror a quaisquer tendências idealistas, digamos assim. História das ideias nos parecia algo livresco, como se um pensamento falasse com o outro. Para ele o essencial eram as condições sociais de existência de toda e qualquer obra cultural, dizia: "Tem que levar em conta o contexto." Abaixo o espiritualismo metafísico. Muito mais tarde, quando voltei para o Brasil, após o ano de 1978, o segundo momento de estágio em Paris para redigir a tese em francês, eu me interessei por uma história das ideias contextualista, através, de novo, da influência dele, porque me fez ler a monografia do [Quentin] Skinner sobre o pintor renascentista Ambrogio Lorenzetti, autor do famoso afresco em Siena: "Esse cara é historia das ideias, mas em outra chave." Comecei a ler a história das ideias no estilo dos trabalhos de [John] Pocock e Skinner pela mesma influência, porque era uma turma atenta ao contexto, à história social e institucional. Bem distinta da história das ideias praticada na América Latina. A cada quinze dias, tínhamos seminário com um autor diferente do qual todos os orientandos tinham de ler na íntegra pelo menos uma obra importante. 
Esse seminário ocorria na École Normale Supérieure; duas vezes por mês, tínhamos a oportunidade de ouvir a exposição de algum luminar, numa semana era Ringer, noutra era Thompson, noutra era Schorske, todos eles amigos próximos de Bourdieu. O nosso espaço exclusivo. Era aí onde se lia a bibliografia internacional. Nós não podíamos perder... quando Ringer veio, todos tivemos que ler Os Mandarins Alemães. Era também o dia, ou melhor, a noite de confraternização dos orientandos com os assistentes, com o patrão e seus convidados. Imperdível.

\section{- JPF: Vocês leram [Richard] Hoggart também?}

Hoggart não apresentou nesse seminário, mas como ele tinha feito a publicação na França do The uses of Literacy [a versão francesa feita por Bourdieu chamou-se La culture du pauvre]... Eu tinha em inglês o livro. Já tinha lido antes de ir para França.

Ele[Bourdieu] tinha muita preocupação de incentivaro conhecimento dos orientandos nessas correntes, nesses autores, que ele considerava importantes, com quem ele estava dialogando. Ele incutiu a exigência de uma formação pluralista e internacional. Passou isso pra gente, não sei se de modo tão consciente. Mas a agenda de seminários teve impacto em nós todos. Basta ler os trabalhos de meus colegas, os textos do falecido [Michäel] Pollak, por exemplo, é forte a presença desses autores no que fazíamos então.

\section{- JPF: Nessa relação que você estabelece com o seu orientador de alguma forma ele representa um modelo de excelência?}

Total, na minha cabeça total.

\section{- JPF: Você teve alguma relação com Jean-Claude Passeron?}

Eu o conheci numa conferência, mas ele já tinha brigado com Bourdieu. Quando cheguei, ele já não estava mais no circulo, eu tive relação próxima com os assistentes que estavam lá: o Chamboredon, Grignon, Luc Boltanski, Yvette Delsaut, Francine Muel-Dreyfuss e a Monique de Saint-Martin, a minha sala era com a Monique. Ela acompanhou a feitura do doutorado, assim, linha a linha. Inclusive me ajudou em muitas formulações para o francês, porque eles têm um jeito de montar as frases... No início, em especial, ela me ajudou bastante. 
O Passeron não. Tenho um orientando, o Alexandre Pires, que diz que eu deveria ler mais o Passeron, que o Bourdieu matou o Passeron dentro de mim, mas não é isso não... É que quando eu cheguei, eles já estavam brigados e o Passeron foi para a escola prática de Lyon, não estou certo.

\section{- JPF: Marseille}

Reli alguma coisa quando escreveu sobre o Weber, mais tarde, na introdução ao volume de ensaios de sociologia da religião. Um sociólogo competente.

- JPF: você leu o Le raisonnement sociologique?

Não... Eu só li coisas dele desse tipo, que eram textos de introdução para coletâneas.

\section{EXCELÊNCIA EM SOCIOLOGIA: UMA PERSPECTIVA SOBRE O MÉTIER}

6 - JPF: Você poderia dizer o que determina as qualidades de um bom sociólogo? Quais são as características de um bom sociólogo para você?

Primeiro: um cientista social tem de ser capaz de aliar a boa formação a uma disposição para o trabalho empírico, para pesquisa, e fazer a liga entre a formação e o suporte empírico, eis um bom sociólogo. Sou um tanto cético com gente que arrota teoria. Ninguém faz teoria sem lastro empírico.

Segundo: quando os grandes sociólogos começam a fazer formulações genéricas, abrangentes, é a partir do trabalho empírico prévio. Não existe sociologia teórica e muito menos teoria sociológica pura.

7 - JPF: Quais seriam as práticas que, segundo você, designam o métier de um sociólogo? Que tipo de prática um sociólogo precisa fazer?

Darei o exemplo concreto de como eu trabalho. Em novembro de 2014, fiz uma conferência sobre a revista argentina $S U R$, o veículo mais 
prestigioso no campo cultural nos anos 30; queria com isso dar um fecho ao trabalho comparado com o caso argentino. Ao se debruçar sobre tal objeto, um crítico literário irá privilegiar a análise de textos e não prestará atenção à morfologia sociológica do objeto. Fiquei um mês em Buenos Aires para ler a revista no período entre 1931 e 1945, fazendo xerox dos materiais mais importantes, anotando os índices, tudo isso. No entanto, o trabalho compreensivo consiste em identificar o círculo de pessoas que está por trás do projeto, saber quem sustenta a iniciativa. Quem são essas pessoas, os aliados da Victoria Ocampo, na turma responsável pela revista? São pessoas que pertencem à elite como ela. Alguns escrevem na revista, são críticos de arte, de música, são colecionadores. Não consigo armar o diagnóstico sem entender esse círculo da elite. O problema não se resolve pelo esclarecimento de quem financia a revista, porque ela era muito rica, e concedia subsídios a fundo perdido. Como sucede o patrocínio social, ou melhor, o que sustenta a crença na legitimidade da revista - órgão emblemático dos valores esposados pelo círculo. $\mathrm{O}$ trabalho inicial foi reconstruir esse grupo, esboçar o retrato coletivo, um trabalho de prosopografia. Não basta ler a revista, cumpre mobilizar as fontes bio-bibliográficas a respeito dos integrantes do círculo. Você tem de trabalhar a contrapelo dos mitos de invenção da revista, todos centrados na figura de Victoria Ocampo, da ação e da iniciativa dela - uma figura quase mitológica. E a surpresa foi a revelação de que o grupo de amigos próximos é tão ou até mais competente que ela em termos culturais, pois são grandes colecionadores de arte, viajantes assíduos à Europa, integrantes de um circuito internacional cosmopolita. Não é possível deslindar a revista sem entender as feições do patrocínio. O caminho fácil é orientar o diagnóstico com base nas diversas biografias da protagonista, nos dez volumes de testemunhos, nos seis tomos de autobiografias. Eis o expediente cômodo de aprontar uma espécie de versão oficiosa. Quando se reconstrói o círculo a que ela pertence, a revista adquire um sentido mais abrangente, o de epicentro do establishment que controla todo o sistema cultural portenho.

\section{8 - JPF: Você poderia descrever aquilo que você considera como qualidades acadêmicas de um estudante de sociologia, como é que você recruta os seus estudantes?}

Eu não recruto estudante. 


\section{- JPF: Não recruta?}

Não. A última vez que dei um curso na graduação, quando eu saí da Edusp, era por volta de 2000-2001. Faz muito tempo, depois disso só dei aula na pós. Então, naquele ano juntei as turmas da tarde e da noite. Tinha quase 150 alunos, na maior sala da faculdade, de oito às onze da noite. Nessa turma tinha gente excelente e dela vieram muitos orientandos, foi a partir da experiência de convívio e discussão no curso: Dmitri Cerboncini Fernandes, ${ }^{6}$ Artur Oliveira Bueno, ${ }^{7}$ por exemplo. Eu não recrutei ninguém. O mesmo também acontece na pós graduação. Tive muitos orientandos que fizeram comigo o seminário de projeto, ou então, que haviam sido meus alunos em outros cursos de pós, como Alexandre Bergamo.

\section{- JPF: Mas a pergunta tem a ver com as perguntas anteriores, existe um modelo de excelência...}

Masédifícil controlar isso... Nem posso reclamar porquetiveexcelentes orientandos. Gente que sabia escrever, o que não é trivial. Houve casos de estudantes com quem tive que ralar bastante, sobretudo na escrita. $\mathrm{O}$ processo se passa da seguinte maneira: o que você está chamando de recrutamento... Os estudantes fazem um cálculo em torno do que percebem como a legitimidade dos orientadores. Existe um anedotário com ampla difusão: quem é mais importante, quem é menos, quem é mais legítimo, quem é mais reconhecido, e os estudantes não estão fora desse jogo. Ou eles procuram ou eles se auto excluem. Tenho certeza que tem gente que deve ter pensado em se candidatar comigo e recuou. Quer dizer, assim como existe porcentual elevado de auto exclusão quando se abre uma vaga na USP para o concurso de sociologia. Muita gente de qualidade intelectual que poderia fazer e que fica temerosa: "Isso não é para o meu bico." A maior dificuldade é quando a pessoa não teve uma formação boa, isso é complicado. Mas também já tive experiência com orientandos

6 Dmitri Cerboncine Fernandes doutorou-se, sob orientação de Miceli, com a tese intitulada Sentinelas da tradição. Sambistas e chorões nas engrenagens da indústria cultural em 2005, na Faculdade de Filosofia, Letras e Ciências Humanas - USP.

7 Arthur Oliveira Bueno doutorou-se, sob orientação de Miceli, com a tese As economias da vida. Dinheiro e arte como formas de vida nos escritos de Georg Simmel em 2014, na Faculdade de Filosofia, Letras e Ciências Humanas - USP. 
sem formação, gente de fora, de outros estados, que conseguiram zerar o prejuízo e crescer do ponto de vista intelectual.

\section{A FORMAÇÃO OFERECIDA NO BRASIL: IMPRESSÕES SOBRE A USP}

9 - JPF: O que você acha da formação nos cursos de sociologia no Brasil? Estou pensando nas universidades federais públicas...

Eu não conheço bem o curso nas universidades federais, mas posso falar a respeito da USP. E dos problemas também, não são só as qualidades. Vamos por exemplo comparar o curso de graduação de ciências sociais na USP com o de história na mesma faculdade. Por que há tanta gente de história que vem fazer matérias em ciências sociais? Porque na história, na verdade, não existe um ciclo básico. O aluno quer ter uma formação básica em historiografia, mas ele não consegue porque já nos primeiros anos os professores querem dar cursos em torno de suas pesquisas. Isso não ocorre em ciências sociais. Você pode dar as optativas no terceiro, no quarto ano, mas os alunos têm um ciclo básico integrando sociologia, antropologia e ciência política. Há enfrentamento e concorrência entre as três disciplinas, mas o ciclo básico é o grande diferencial porque garante o lastro de formação na tradição intelectual da disciplina. Os alunos não precisam aprender os conceitos de cor, nada disso é necessário, mas se você, no aprendizado inicial, não enfrentou Weber, Durkheim e Marx, eis uma carência incontornável. O estudante tem que apreender a contextualização dos sistemas de pensamento do mundo social para atinar com a sociologia contemporânea. Agora qual é o defeito do curso? Há pouca sociologia contemporânea. Após anos de discussão, algumas optativas começaram a enfrentar o assunto. A força do curso reside no ciclo básico, e a dificuldade é que muitos alunos vão aprender sociologia contemporânea apenas no doutorado. 


\section{PARTE 2 - SOCIABILIDADE: ALCANCE E LIMITE DA SUSTENTAÇÃO PRÁTICA DE UM MODO DE FAZER BOURDIEUSIANO EM SÃO PAULO}

\section{0 - JPF: Você se considera um intelectual com discípulos? Você acha que fez escola? Existe uma corrente miceliana de sociologia?}

Não. Tenho colegas que trabalham muito próximos, mas seria exagero dizer que existe uma escola. Maria Arminda, Fernando Pinheiro, Luiz Carlos Jackson, Heloisa Pontes, Fernanda Peixoto, Silvana Rubino, Lília Schwarcz entre outros, se aproximaram, em circunstâncias distintas, e continuam em sintonia até hoje. Um elemento decisivo para a liga do grupo inicial foi a experiência compartilhada na feitura do projeto História das ciências sociais no $\mathrm{Brasil}_{,}^{8}$ um trabalho de cinco anos com uma equipe que trabalhou junto muito tempo, e cujos objetos de tese foram sendo definidos em função da divisão do trabalho na pesquisa, eis o germe do grupo. Depois disso houve outras oportunidades de trabalho coletivo: um outro projeto da FINEP, uma História social da arte no Brasil, que não deu muito certo, mas que durou dois anos; e ainda o projeto temático na USP, e mais os seminários latino-americanos no andamento da elaboração dos volumes da História dos Intelectuais na América Latina (já editado em 2 tomos) e sobre a memorialística latino-americana (Edusp, no prelo). Em resumo, por conta dessas experiências sucessivas, foi se constituindo um grupo de cientistas sociais que compartilha o mesmo universo de preocupações sobre o mundo social. Nesse sentido, admito a existência do grupo com afinidades, não de uma escola.

\section{1 - JPF: Quem são os seus principais parceiros de trabalho? E quem são seus interlocutores? São duas perguntas.}

Interlocutores... a equipe da história das ciências sociais continuou muito ligada comigo... Primeiro trabalhamos juntos aí e em outra pesquisa financiada pela FINEP. E depois no temático, muitos deles voltaram a trabalhar comigo durante quatro anos. São colegas procedentes de diversas disciplinas, antropologia, sociologia, história. Uma turma que trabalha

8 Trata-se do grupo que participou do projeto de pesquisa que produziu o livro em dois volumes História das ciências sociais no Brasil. 
com esse tipo de objeto no Brasil. São também interlocutores, aos quais posso juntar colegas do Rio de Janeiro, atuantes na mesma seara - Maria Alice Rezende de Carvalho, Ricardo Benzaquen -, e mais os amigos latinoamericanos, em especial a parceria argentina com Alejandro Blanco, Carlos Altamirano e Adrián Gorelik. Muitos orientandos se tornaram amigos e interlocutores, inclusive alguns, como o Luiz Carlos Jackson, dos quais não fui orientador formal. Sem esquecer parceiros mais recentes como Marcelo Ridenti, Esther Hamburger e Heloisa Buarque de Holanda. Mas minha parceira mais presente e mais crítica tem sido minha mulher, Heloisa Pontes.

\section{- JPF: Os adversários que você respeita}

Não são a rigor adversários, mas amigos com perspectivas distintas de trabalho intelectual. Tenho respeito e admiração por todos eles, em especial Roberto Schwarz, Davi Arrigucci Jr., Antonio Arnoni Prado, entre outros. Já escrevi a respeito de trabalhos de todos eles, textos que revelam os pontos possíveis de aproximação e de distância. Por conta da formação em ciências sociais, Roberto me parece mais aberto para a visada sociológica e preocupado com uma interpretação macro da matéria literária, enquanto Davi me parece mais antenado com a dimensão estética sem descurar da experiência social. Como Davi e eu nos encontramos toda semana, acabo tendo mais conversas e divergências, embora haja um acordo tácito, me parece, de até onde pode chegar a peleja. O desacordo surge e tentamos lidar do melhor jeito; não se trata apenas de dissenso em matéria cultural, mas também de temas políticos e até de juízos sobre produtos da indústria cultural. Aprecio interlocutores com pegada analítica bem diferente da minha. Na Argentina, também tenho amigos próximos que tiveram uma formação mais literária do que sociológica, o que não impediu que fizéssemos projetos em parceria.

\section{2 - JPF: Tem alguma querela acadêmica na qual você lembra de ter participado? Que de alguma forma teria sido importante ao ponto de delinear o contorno de seu trabalho?}

Nenhuma querela delineou o contorno do meu trabalho. Houve um bate boca interessante, com um escritor-jornalista que nem é sociólogo. 
Fui curador de uma exposição ${ }^{9}$ de retratos após a publicação de Imagens Negociadas, ${ }^{10}$ no Centro Cultural do Banco do Brasil, no Rio de Janeiro. Fiz uma seleção de retratos, e o CCBB conseguiu a cessão das obras. O desafio me agradou. Fiz um pequeno texto de abertura para o catálogo da mostra. O texto retomava as teses centrais do livro, inclusive das tratativas de negociação envolvendo a feitura dos retratos entre os clientes - políticos, escritores - e os pintores. Um dos artistas em foco era Candido Portinari, o que desagradou muita gente. Moacyr Werneck de Castro escreveu um artigo na imprensa, descendo a lenha nos critérios e na interpretação do curador. Eu conhecia um dos livros dele, sobre o período de 'exílio' de Mario de Andrade no Rio de Janeiro, talvez o melhor testemunhoa respeito. Um livro comovente que documenta bem esse momento da trajetória de Mário. Pois bem, eu acabei respondendo às críticas e a polêmica parou por aí. Ele lançou um manifesto anti-sociológico, eu defendi minha posição.

\section{3- JPF: Quem são seus interlocutores fora do Brasil ?}

Alguns colegas que se formaram comigo, com alguns deles eu mantive uma conversa produtiva, com Lygia Sigaud, por exemplo; mas também com os então jovens que foram meus contemporâneos no círculo em torno de Bourdieu, como Louis Pinto, Christophe Charle, Gisèle Sapiro, Afrânio Garcia, entre outros. " Para Gisèle, escrevi o artigo sobre Borges, publicado em Actes de la Recherche; ela é bem mais jovem, mas o fato de trabalhar com sociologia da literatura nos aproximou.

9 Trata-se da exposição "Imagens Negociadas. Retratos da elite brasileira" realizada no CCBB do Rio de Janeiro entre julho e outubro de 1998.

10 Trata-se do livro Imagens negociadas. Retratos da elite brasileira (1920-1940).

11 Trata-se do livro: A gênese da sociedade do espetáculo: teatro em Paris, Berlim, Londres e Viena. 
14 - JPF: Como você vê sua posição na USP em relação a outros tipos de trabalho? Quero com essa pergunta entender se o fato de você ter estudado diretamente com Pierre Bourdieu afeta de alguma forma a maneira mais filtrada pela qual as pessoas olham a partir do mesmo referencial bourdieusiano, mas sem ter tido o contato direto com o ambiente que produziu aquele pensamento. Se você sente de alguma forma essa distancia entre o Bourdieu de seu trabalho e o de outros que trabalham a partir do referencial dele?

Salvo engano, acho que não. Voltemos no tempo, pois ajuda a esclarecer o foco da pergunta. Após a defesa do mestrado, eu, Maria Celia Paoli, Maria Helena Augusto e Irene Cardoso fomos convidados para ingressar como docentes no Departamento de Sociologia da Universidade de São Paulo. Decerto porque éramos estudantes qualificados da pós-graduação. Eu havia atuado como representante discente na comissão de pós-graduação. Meu orientador na época era Octávio Ianni, que tinha sido aposentado. Quem me transmitiu o convite, em nome do departamento, foi o Leôncio Martins Rodrigues (meu orientador no mestrado). Fiquei exultante, mas, por razões de lealdade que me pareceram justas, antes de dar resposta, falei com Ianni para saber sua opinião. Para mim seria ótimo, era um emprego que viria a calhar com o final da minha bolsa Capes. Ele me disse: "Não, eu vou te arranjar um outro emprego no interior, você vai entrar pela minha mão.” Por conta disso, acabei declinando, fui o único que não aceitei. Uma burrada monumental, para a qual não atino bem até hoje! Não era pouca coisa, sobretudo para um forasteiro carioca. No entanto, o mau passo acabou tendo um lado positivo. Fui obrigado a me virar; fui ensinar no interior e logo me dei conta de que não queria isso. Então fiz o concurso de ingresso na Fundação Getúlio Vargas, onde trabalhei quase vinte anos. Tive condições de ter a bolsa para a Europa, que dificilmente eu teria se estivesse atuando como docente na USP. Quase ninguém na USP da minha geração foi para o exterior. Todos estavam lá ralando, inclusive por conta da carga redobrada com as aposentadorias. Tive condições de ter recursos abundantes para pesquisa, cinco assistentes para auxiliar no levantamento prosopográfico da inteligência brasileira, tarefas que eu nunca poderia ter feito sozinho. $\mathrm{O}$ livro $^{12}$ sobre os intelectuais contou com o trabalho coletivo de uma equipe;

12 Trata-se do livro Intelectuais e classe dirigente no Brasil (1920-1945). 
fazer o levantamento de 15 anos de nomeações dos intelectuais para o serviço público não era tarefa a ser cumprida em voo solo. Em 1984, ainda na FGV, fui eleito secretário-executivo da ANPOCS, e logo fui convidado para ensinar na pós-graduação em Campinas, onde permaneci até 1989. Fiz a carreira na diagonal, por assim dizer, de fora para dentro. Em 1989, recebi outro convite para ingressar na USP, chamado desta vez por dois departamentos, na mesma semana: o de ciência política e o de sociologia. Embora tivesse muitos amigos em ciência política, optei pela sociologia porque, de um lado, sempre me enxerguei como sociólogo e, de outro, porque havia maiores chances de me tornar professor titular na sociologia. Os cargos de titular em ciência política estavam preenchidos e haveria em breve vagas em sociologia. Eu já era livre-docente, o que facilitava o pleito.

- JPF: Não. É mais o seguinte. Existe um filtro específico: você não é o único brasileiro a quem se pode associar à sociologia bourdieusiana no Brasil.

Claro que não.

- JPF: A pergunta se refere a como é que você percebe esse contraste, você é dentre as pessoas que reivindicam a filiação ao Bourdieu que eu conheça o único que trabalhou diretamente com ele, certo?

De fato, nenhum outro brasileiro fez doutorado com ele, nenhum outro latino- americano.

- JPF: Isso não causa um impacto no jeito de fazer, está entendendo onde eu estou querendo chegar?

Vamos equacionar a questão de outro modo. Cumpre atentar para a seguinte constatação, a despeito do meu caso em particular. Sem o Bourdieu, a sociologia estaria mal das pernas na competição interdisciplinar no mundo contemporâneo, eis a minha opinião. Trata-se de algo irrefutável, o qual pode ser aferido pelo número de citações, tanto no Brasil como no resto do mundo, pelo impacto da obra, pela quantidade de línguas em que as obras foram traduzidas. Não depende de mim, não é um problema de filtro. 
- JPF: Durante a entrevista até aqui você vem me dando pistas sobre um jeito específico de fazer sociologia ligada a uma formação [aprendizado] e uma prática sociológica.

Que talvez tenha sido o aspecto mais valorizado quando fui novamente convidado. Nessa ocasião, fui chamado para dar uma aula para os professores a respeito do meu trabalho; percebi ali que havia certo fascínio pelo trabalho de investigação que havia realizado. Decerto a crença no vigor da teoria pura ficara um tanto abalada. Eis as circunstancias: tinha 43 anos quando ingressei na USP, com doutorado publicado em livro que tivera ampla repercussão, e já havia me tornado livre-docente na Unicamp com a tese sobre a elite eclesiástica brasileira. Dito de outro modo, entrei trunfado e pronto para entrar na fila de acesso à posição de professor titular, o que deve ter incomodado alguns colegas que se haviam atrasado na carreira.

\section{PARTE 3 - SOCIOLOGIA E LITERATURA: DIFERENTES EMPREITADAS}

\section{UMA POSIÇÃO MAIS SOCIOLÓGICA E MENOS DE HISTÓRIA DAS IDEIAS: ASPECTOS DA VIVÊNCIA NA ANPOCS E NA USP}

15 - JPF: O pensamento social brasileiro, o que é que para você designa essa categoria?

Isso aí é parte da minha experiência de convívio e de aprendizagem. O grupo de pensamento social na ANPOCS fez um seminário no Rio de Janeiro em homenagem ao meu trabalho, com análises instigantes, que me comoveu bastante. Desde o início, participei desse grupo na ANPOCS, ${ }^{13}$ discutindo e defendendo uma posição sociológica em contraposição à história das ideias, do pensamento puro. O embate foi frutífero. Não obstante, exceto o livro do Ricardo Benzaquem, Guerra e Paz, sobre o Gilberto Freyre, dotado de força analítica e de argumentos sólidos, nenhuma outra obra nessa linhagem de história do pensamento teve impacto na sociologia brasileira. No mais das vezes, as análises ditas

13 Associação Nacional de Pós-Graduação e Pesquisa em Ciências Sociais. 
internas de pensamento social consistem em paráfrases, redundantes e destituídas de aguilhão interpretativo. Talvez seja uma tradição que sobreviveu mais no Rio, por razões que caberia esclarecer em termos de história intelectual.

16 - JPF: Você tem uma posição bem clara quanto à sociologia das ideias e do pensamento, sobretudo como elas se dão aqui no Brasil (que é o que você vem dizendo). Você poderia elaborar em que momento da sua carreira você entendeu que essas posturas não rendiam tanto?

Pergunta esperta. Não sei se tive ciência de forma tão consciente disso. A postura reativa foi se definindo meio na marra. Quando comecei o trabalho para o doutorado, eu lia os romances, as obras, a poesia dos modernistas e, em paralelo, lia também as biografias, as autobiografias. Eram duas frentes de indagação, e fui me dando conta de que os avanços da argumentação foram dependendo mais das fontes biográficas e autobiográficas do que das obras. Não que as obras não tivessem importância, mas não me pareceram suficientes para compor o retrato coletivo dos intelectuais. De fato, em vista dos alvos que estava perseguindo, as obras por vezes se interpunham como cabresto. Em suma, os textos literários validavam os achados, sem dar conta do retrato coletivo do grupo. Mas tais passos não foram tão conscientes, nem pré-determinados, foram sendo acertados no correr da investigação. Depois, fiz análises da elite eclesiástica, tangenciei os militares (que não desenvolvi muito), e nesses casos a questão das obras não fazia sentido. Quando voltei a me defrontar com material artístico-literário no caso do modernismo, os desafios eram distintos e talvez eu estivesse mais aparelhado para lidar com a produção artística e literária.

\section{- JPF: Nacional Estrangeiro?}

Exatamente. Então eu mobilizei um método de análise da obra pelo caminho da história social da arte e não da crítica de arte formalista. Os modelos no bastidor da argumentação sustentada no Nacional Estrangeiro procedem da história social da arte, ou seja, Antal, Wind e os demais já mencionados. Bourdieu costumava insistir para que os orientandos fossem bastante reflexivos quanto às fontes e à metodologia. Quando 
conversamos a respeito do livro sobre os retratos da elite brasileira, que havia sido publicado, ele reiterou a necessidade de deslindar a metodologia aí empregada. Quero dizer que não se trata de uma conduta tão cerebrina, calculada, porque de fato a cada nova investigação você sente-se desafiado a lidar com materiais novos que induzem a mediações surpreendentes. Cada acervo documental é uma provocação diferente. Não existem receitas de método. A análise dos retratos em Imagens Negociadas é distinta daquela empreendida no Nacional Estrangeiro, e mais ainda das interpretações feitas acerca dos intelectuais argentinos. Respostas arrumadas não dão conta do problema, a ser enfrentado com feições impregnadas pelas fontes com que se está lidando.

\section{TRANSITIVIDADE:A LITERATURA PARA A SOCIOLOGIA DE MICELI E A SOCIOLOGIA NA CRÍTICA LITERÁRIA DE CANDIDO}

17 - JPF: Em alguns trabalhos recentes você tem feito de forma mais detida análises mais próximas daquilo que se convencionou chamar de análise de conteúdo, tratando mais especificamente das obras dos intelectuais e artistas. Como você lê esse seu movimento no conjunto dos seus trabalhos?

No livro a respeito dos intelectuais, ${ }^{14}$ o único momento em que se analisa alguma obra é no capítulo dos romancistas e, assim mesmo, em diagonal. No caso do Nacional Estrangeiro, tive de encontrar meios de tematizar as obras, inclusive os retratos, em chave contextualista. No artigo $^{15}$ sobre a história social de Borges, quis analisar a estreia poética, Fervor de Buenos Aires, valendo-me da pinça sociológica que encontrou nos versos matéria apropriada. Os instrumentos nem variam tanto, o que acalma os devotos do pensamento puro é o rótulo; assim, o emprego da expressão "história social", por exemplo, parece sedativo, calmante, o efeito contrário sendo provocado pelo qualificativo de "sociológico", o qual tem o condão de levar os estetas ao estado de choque. A rigor, as

\footnotetext{
14 Trata-se do livro Intelectuais e classe dirigente no Brasil (1920-1945).

15 Já referido anteriormente, o artigo Jorge Luis Borges, histoire sociale d'un « écrivain-né " publicado no $\mathrm{n}^{\circ} 168$ da revista Actes de la recherche en sciences sociales.
} 
obras culturais são práticas sociais como as demais e merecem ser tratadas sem contorcionismo heurístico.

18 - JPF: Você acha que a sociologia ganha contornos específicos quando usada para analisar uma obra literária para fim próprio e outros quando para um fim de crítica literária?

Uma coisa não tem nada a ver com a outra. São coisas diferentes. São empreitadas diferentes.

19 - JPF: Vamos pensar o caso de Antônio Candido, e daquilo que se fala que é sociologia da literatura a partir da obra dele. Como é que você enxerga o Antonio Candido?

Antônio Candido, o Verdi de todos nós, realizou obra ímpar e de impacto tangível sobre minha geração. No entanto, toda obra intelectual é fruto das suas condições históricas de produção. $O$ trabalho de Candido é um caso, vamos dizer assim, transitivo, entre um momento de germinação das ciências sociais no país e a conjuntura subsequente de institucionalização, quer do ponto de vista do objeto que ele concebeu, quer no que respeita aos métodos utilizados. Embora tenha incorporado a formação em ciências sociais, praticando a docência em sociologia durante quinze anos, se redefiniu como crítico literário, como professor de literatura comparada e de teoria literária. Tais transições foram impondo movidas sutis no trabalho de auto-definição, algo perceptível por meio da leitura dos textos nos diferentes períodos. Ele buscou, como era de se esperar, não rechaçar, mas abrandar o componente sociológico em prol do que passou a nomear como propriamente literário. Algo que é difícil de atinar, mas isso não vem ao caso por ora. O intento de trilhar e abraçar uma vocação literária trouxe alguma recompensa, mas nunca conseguiu livrálo da 'pecha' sociológica, o que talvez estivesse no cálculo. Teve de lidar com uma recepção que insistiu em não livrá-lo do encaixe sociológico; por mais que tenha se empenhado em se distinguir da sociologia, a fortuna crítica e mesmo a inteligibilidade do seu trabalho nunca dissociou o teor substantivo do lastro sociológico. Tal recepção não se deveu apenas a jornalistas, mas também aos críticos literários e escritores. Faz tempo tive uma conversa com o Roberto Schwarz: não adianta se empenhar em frisar que presta atenção na forma estética do texto, na medida em que 
a substância de sua interpretação toma folego por outros combustíveis, pelo fato de embutir a diagnose da história da sociedade brasileira. Eis o resumo da ópera. A tentativa de se legitimar pelo alto não se consuma por força das relações de competição no interior do campo intelectual. A força deles deriva do lastro sociológico; reverenciados ou atacados, serão sempre designados e qualificados como sociológicos. Melhor assumir a carapuça.

Eu nunca quis ser crítico literário, nunca estudei nem ensinei literatura. A literatura, para mim, é um objeto de reflexão sociológico, é um material disponível para a reflexão sociológica, quer dizer, não tenho nenhuma pretensão de fazer análise estética, e muito menos de exercer poderes de árbitro nessa seara. Nem sei como fazer e não fui treinado para tal magistratura. Ademais, é preciso ter a crença e acreditar que isso tem um valor. Se o trabalho que faço incomoda, incomodo como sociólogo e não como concorrente.

\section{0 - JPF: Mas você caracterizaria os elementos da análise do Candido como uma análise sociológica da literatura, ou não?}

As magníficas análises do Candido, sem a sociologia, escusado dizer, não ficariam de pé um segundo. A análise de Memórias de um Sargento de Milícias, do Aluízio de Azevedo, os grandes textos do Candido se apoiam numa visada sociológica da sociedade brasileira. 